DOI: https://doi.org/10.47405/mjssh.v6i7.909

\begin{tabular}{|c|c|}
\hline 4 & Malaysian Journal of Social Sciences and Humanities (MJSSH) \\
\hline $\begin{array}{l}\text { Malaysian Journa of } \\
\text { Social cciences and }\end{array}$ & Volume 6, Issue 7, July 2021 \\
\hline (MJ-sSH) & e-ISSN : 2504-8562 \\
\hline & $\begin{array}{l}\text { Journal home page: } \\
\text { www.msocialsciences.com }\end{array}$ \\
\hline
\end{tabular}

\title{
Satu Tinjauan Terhadap Pemikiran dan Idea Bunuh Diri dalam kalangan Pelajar
}

\author{
Abdul Rashid Abdul Aziz ${ }^{1}$, Nor Hamizah Ab Razak ${ }^{1}$ \\ 1Fakulti Kepimpinan dan Pengurusan, Universiti Sains Islam Malaysia (USIM) \\ Correspondence: Abdul Rashid Abdul Aziz (rashid@usim.edu.my)
}

\begin{abstract}
Abstrak
Ketika ini, statistik kes bunuh diri di Malaysia dilihat sedang mengalami peningkatan yang mendadak. Fenomena ini diburukkan lagi dengan penularan wabak COVID-19 yang kian mengganas. Penularan wabak COVID-19 ini telah memberikan banyak implikasi buruk kepada pelbagai lapisan masyarakat. Hal ini tidak terkecuali dalam kalangan pelajar. Justeru, kajian ini bertujuan untuk melihat tahap idea dan pemikiran bunuh diri dalam kalangan golongan muda yang terdiri daripada pelajar. Kajian ini berbentuk tinjauan deskriptif dengan menggunakan persampelan rawak mudah melibatkan 120 responden. Soal selidik yang digunakan adalah soal selidik Adult Suicidal Ideation Questionnaire (ASIQ) yang mengandungi 25 item. Data kajian dianalisis menggunakan Program Statistical Package for Social Science (SPSS) versi 23 untuk menganalisis data statistik deskriptif. Hasil kajian mendapati bahawa skor yang melebihi nilai batasan (cut-off score) iaitu 31 dan lebih, menunjukkan tahap pemikiran responden ke arah bunuh diri dan memerlukan intervensi dari kaunselor mahupun psikiatri. Nilai min bagi jumlah skor responden ialah 11.2, manakala sisihan piawainya 17.8. Terdapat lima orang responden mencatatkan jumlah skor melebihi daripada 31 yang menunjukkan bahawa golongan ini mempunyai tahap pemikiran dan idea bunuh diri yang tinggi. Konklusinya, kajian ini dapat membuka mata ibu bapa dan pihak pengurusan Universiti berkaitan kebarangkalian pelajar untuk mempunyai pemikiran dan idea bunuh diri. Sekiranya masalah ini dapat dikenalpasti lebih awal, pelajar boleh dirujuk untuk penilaian dan penerokaan dengan lebih lanjut melalui intervensi secara klinikal agar kejadian bunuh diri dapat dielakkan.
\end{abstract}

Kata kunci: pemikiran, idea bunuh diri, pelajar, Adult Suicidal Ideation Questionnaire

\section{A Survey of Suicidal Thoughts and Ideas Among Students}

\begin{abstract}
Nowadays, the statistics of suicide cases in Malaysia are seen to be increasing in trend. This phenomenon is exacerbated by the outbreak of COVID-19 pandemics. The spread of the COVID-19 pandemics had caused a lot of adverse effect for a multiple age ranges in Malaysian society. This is no exception among students. Thus, this study aims to look at the level of suicidal ideas and thoughts among young people consisting of students. This is a quantitative survey study using simple random sampling involving 120 respondents. Adult Suicidal Ideation Questionnaire (ASIQ) which contained 25 items was used in this study. The descriptive statistical data was analyzed using Statistical Package for Social Science (SPSS) version 23. The study found that the score which exceeded the cut-off score of 31 and more, indicates the level of respondents' thoughts towards suicide is high and requires intervention from a counselor or psychiatrist. The mean value of the total score of the respondents is
\end{abstract}


11.2, while the standard deviation is 17.8. There were five respondents recorded a total score of more than 31 which indicates that this group has a high level of suicidal thoughts and ideas. In conclusion, this study is believed to be able to increase awareness among parents and University management team regarding the probability of students to have suicidal thoughts and ideas. If the problem can be identified earlier, students can be referred for further assessment and exploration through clinical interventions so that suicidal incidents can be avoided.

Keywords: thoughts, suicidal idea, students, Adult Suicidal Ideation Questionnaire

\section{Pengenalan}

Bunuh diri adalah tingkah laku yang dahulunya jarang-jarang berlaku dalam masyarakat Malaysia namun kini menjadi polemik yang semakin membimbangkan disebabkan peratusan dan angka bunuh diri yang meningkat saban tahun. Pendedahan berkaitan bunuh diri kebiasaannya melibatkan kes-kes luar negara. Namun, sejak akhir-akhir ini tingkah laku bunuh diri sudah menjadi satu perlakuan yang tidak janggal lagi dalam kalangan masyarakat terutamanya remaja. Justeru, kejadian bunuh diri dan percubaan bunuh diri telah menjadi suatu masalah kesihatan masyarakat yang utama. Kebanyakan kes bunuh diri di Malaysia dikelaskan sebagai kes kematian tak diketahui (undetermined deaths) dan kadar percubaan bunuh diri pula adalah sekurang-kurangnya 10 kali ganda berbanding kadar bunuh diri (Maniam, 2010).

Secara umumnya, bunuh diri didefinisikan sebagai tingkah laku meragut nyawa sendiri dengan menganggap bahawa masalah akan selesai sebaik sahaja membunuh diri (Hong \& Mohammad Aziz, 2018). Manakala menurut Ame dan Salleh (1995) pula, bunuh diri adalah tingkah laku seseorang yang mengambil nyawa sendiri dengan sengaja yang berhubung kait dengan komponen biologikal, sosial dan psikologikal. Tingkah laku membunuh diri terdiri daripada 3 spektrum iaitu pertama idea bunuh diri yang merujuk kepada pemikiran untuk terlibat dalam tingkah laku yang bertujuan untuk mengakhiri kehidupan. Kedua, rancangan membunuh diri yang merujuk kepada rancangan seseorang untuk mati dan terakhir adalah cubaan membunuh diri iaitu penglibatan dalam potensi tingkah laku mencederakan diri di mana sekurang-kurangnya ada niat untuk mati (Matthew, 2008). Kesemua tingkah laku ini bukan sahaja memberi kesan kecederaan fizikal atau mengundang maut kepada individu tersebut malah turut memberi kesan emosi yang amat dahsyat kepada keluarga serta memberi impak negatif kepada perkembangan sosial, ekonomi dan juga politik negara. Bahkan, statistik yang dikeluarkan oleh Polis Diraja Malaysia (PDRM) menunjukkan kes bunuh diri pada 2019 adalah sebanyak 609 kes diikuti sebanyak 631 kes bagi tahun 2020. Angka ini terus melonjak ke tahap yang lebih membimbangkan di mana dalam tempoh bulan Januari hingga Mei tahun 2021, terdapat sebanyak 468 kes telah direkodkan (Hafidzul, 2021). Risiko membunuh diri dalam kalangan pelajar dan remaja juga semakin merisaukan apabila telah dikenal pasti remaja seawal usia 13 tahun disahkan mempunyai kecenderungan untuk membunuh diri.

Menurut statistik terdahulu yang dikeluarkan National Suicide Registry Malaysia (NSRM), trend angka bunuh diri meningkat sejak tiga tahun kebelakangan dengan jumlah keseluruhan mangsa bunuh diri sebanyak 1,100 (Laporan NSRM, 2010). Manakala statistik negara menunjukkan bahawa wanita melebihi lelaki dalam nisbah 3:1 bagi kadar bunuh diri dan Bangsa Cina mencatat angka tertinggi dalam kadar bunuh diri iaitu 48\%, diikuti India sebanyak 21\%, Melayu sebanyak 18\% dan lain-lain bangsa pula sebanyak 13\% (The Star Online, 2012). Menurut Farberow dan Shneidman (1961), konsep 'Cry for help' atau menangis untuk bantuan sering digunakan bagi kes percubaan bunuh diri. Konsep ini juga sering digunakan bagi menggambarkan percubaan bunuh diri yang mempunyai potensi yang rendah untuk kematian dan kemungkinan yang rendah untuk berjaya bunuh diri (Reynolds, 1991). 


\section{Pemikiran Bunuh Diri}

Umumnya, kehidupan seseorang individu sangat dipengaruhi oleh tahap kesihatan mental. Gangguan terhadap kesihatan mental merupakan punca utama yang mendorong individu bertindak untuk membunuh diri (Louise, 2018). Kementerian Kesihatan Malaysia (KKM, 2013) telah menjelaskan kesihatan mental sebagai satu keadaan yang sejahtera di mana seseorang menyedari tentang keupayaan diri, dapat mengendalikan tekanan dengan baik, dapat bekerja secara produktif dan mampu menyumbang kepada masyarakat. Bagi individu yang sihat mental, mereka cenderung untuk menjalani kehidupan dengan harmoni serta dapat membentuk perhubungan yang baik dengan masyarakat dan persekitaran (Suhaimi \& Rozita, 2017). Sebaliknya, bunuh diri pula adalah rentetan dari tekanan psikologikal yang mengalami satu keadaan yang mengejut dan tragis serta tindakan yang terdesak. Rata-rata individu yang membuat percubaan bunuh diri mengalami tekanan (distress) yang sangat besar. Kebanyakan dari mereka telah melalui tahap tekanan yang tinggi dan melihat bahawa bunuh diri merupakan jalan akhir kepada penyelesaian tekanan atau masalah semasa yang dihadapi. Tingkah laku bunuh diri ini juga biasanya dilakukan oleh individu yang mengalami kemurungan yang tinggi, kelunturan semangat hidup dan kekecewaan yang besar.

Tingkah laku membunuh diri merupakan satu sebab daripada gangguan psikologikal dan berkait juga dengan keadaan kesihatan mental dan fizikal individu. Tingkah laku bunuh diri ini dikategorikan dalam beberapa aspek seperti penyelesaian akhir melalui tindakan bunuh diri, percubaan bunuh diri, niat secara terbuka untuk bunuh diri, pemikiran ke arah bunuh diri (Reynolds, 1991). Istilah 'parasuicide' digunakan untuk menggambarkan percubaan untuk bunuh diri yang tidak berhasil atau tidak berjaya yang disebabkan oleh pelbagai 'kesakitan diri' yang dialami individu. Selain itu, istilah tersebut juga digunakan untuk individu yang membuat ancaman untuk bunuh diri secara terbuka. Menurut kajian Silver, Goldstein dan Silver (1984), bunuh diri merupakan penyumbang kedua terbesar dalam kematian pelajar-pelajar kolej. Walau bagaimanapun, kajian Vaillant dan Blumenthal (1990) di dalam William Reynolds (1991) menyatakan bahawa tingkah laku bunuh diri menjadi semakin bermasalah mengikut jangka hayat atau peningkatan umur individu. Kefahaman dan peringkatperingkat dalam komponen tingkah laku bunuh diri dapat dilihat dalam gambar rajah di bawah.

Rajah 1: Kontinum pemikiran dan tingkah laku bunuh diri

\begin{tabular}{|c|c|}
\hline$\downarrow_{\text {TINGGI }}$ & 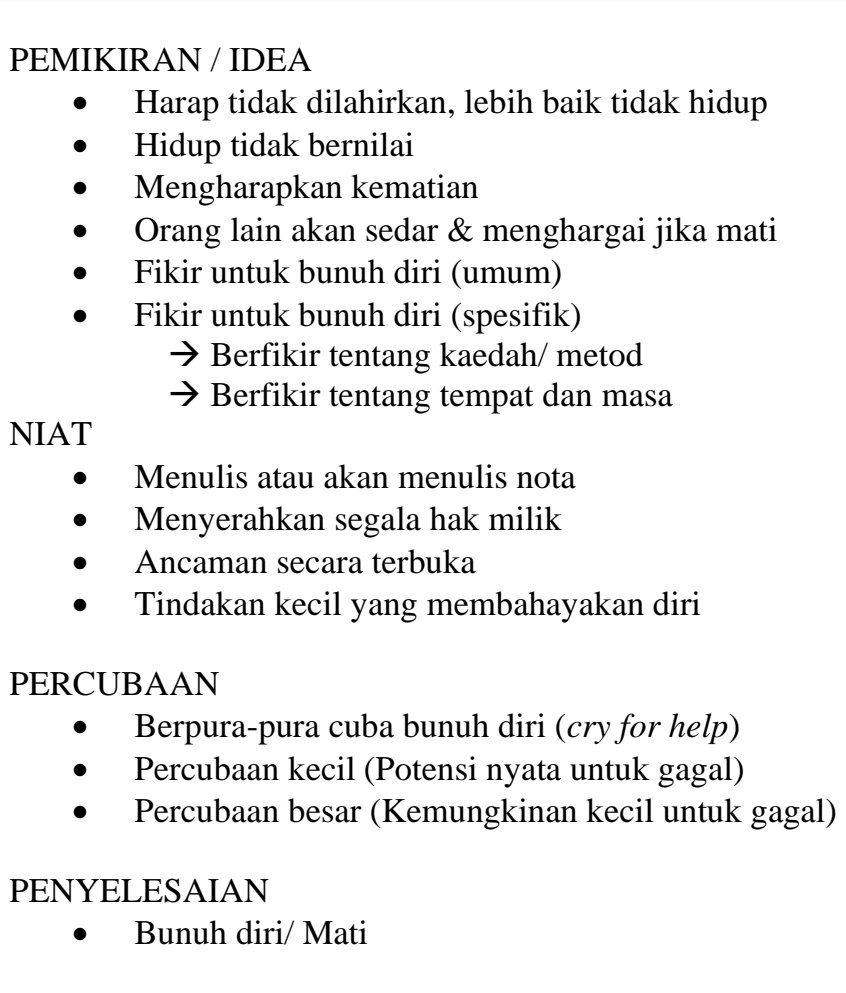 \\
\hline
\end{tabular}


Peningkatan dalam jumlah individu membunuh diri yang kian meruncing dan serius ini memerlukan satu prosedur atau penilaian yang sah bagi mengukur pemikiran bunuh diri di kalangan individu yang terlibat ataupun mempunyai kecenderungan ke arah itu. Hal ini penting bagi mengesan lebih awal lagi gejala dan faktor-faktor seperti kemurungan yang dikaitkan dengan tingkah laku individu yang boleh menyebabkan kematian atau mempunyai potensi bunuh diri. Oleh itu kajian ini bertujuan untuk melihat tahap idea dan pemikiran bunuh diri dalam kalangan golongan muda yang terdiri daripada pelajar.

\section{Sorotan Literatur}

Bunuh diri bukanlah merupakan satu isu baru. Kini, penekanan diberikan kepada isu bunuh diri ini bagi mengenal pasti tingkah laku yang berisiko tinggi kepada perlakuan dan tindakan bunuh diri. Hal ini disebabkan oleh peningkatan dalam insiden bunuh diri di kalangan remaja. Dalam laporan yang dikeluarkan oleh Pertubuhan Kesihatan Dunia atau World Health Organization (WHO, 2021) pada tahun 2019, terdapat lebih daripada 700000 individu yang mati kerana bunuh diri setiap tahun di seluruh dunia. Nisbah kematian disebabkan bunuh diri adalah satu dari setiap 100 kematian. Setiap tahun, bilangan individu yang mati akibat bunuh diri adalah lebih ramai berbanding HIV, malaria, barah payudara atau perang dan pembunuhan. Untuk setiap satu kes bunuh diri, terdapat lebih banyak kes melibatkan percubaan bunuh diri. Bunuh diri adalah penyebab kematian keempat utama pada remaja berumur 15-19 tahun. Manakala, 77 peratus kes bunuh diri global berlaku di negara berpendapatan rendah dan sederhana. Pengambilan racun perosak, gantung diri dan senjata api adalah antara kaedah bunuh diri yang paling biasa berlaku di seluruh dunia.

Di luar negara, seperti di Amerika Syarikat, bunuh diri berada di tempat kesepuluh bagi penyebab utama kematian. Laporan Data dan Statistik Kecederaan Maut (Data and Statistics Fatal Injury Report) yang dikeluarkan oleh Pusat Kawalan dan Pencegahan Penyakit (Centers for Disease Control and Prevention, CDC) menyatakan bahawa pada tahun 2019, terdapat 47,511 rakyat Amerika yang mati kerana membunuh diri dan dianggarkan terdapat sebanyak 1.38 juta rakyat turut terlibat dalam cubaan membunuh diri. Dalam laporan yang sama, kadar bunuh diri adalah tertinggi pada lelaki kulit putih pertengahan umur dan kaum lelaki yang mati disebabkan bunuh diri adalah 3.63 kali lebih kerap berbanding wanita. Tambahan itu, secara purata terdapat 130 kes bunuh diri setiap hari di Amerika Syarikat. Malah, di dalam perinciannya menunjukkan bahawa bunuh diri menggunakan senjata api menyumbang kepada 50.39 peratus daripada kesemua kematian akibat bunuh diri.

Sementara itu, kajian yang dijalankan oleh Siti Norma dan Salleh Amat (2018) terhadap beberapa pelajar kolej mengenai niat bunuh diri dengan menggunakan kaedah temu bual telah menghuraikan bahawa terdapat beberapa faktor yang dikenal pasti menyebabkan responden berniat untuk bunuh diri. Antara faktor- faktor tersebut ialah, pertama faktor persekitaran yang merangkumi aspek keluarga, rakan sebaya, percintaan dan pembelajaran. Kedua, faktor rakan sebaya yang tercetus disebabkan oleh konflik yang berlaku di antara rakan. Ketiga, faktor keluarga yang berpunca disebabkan wujud masalah dalam keluarga seperti isu ibu bapa pilih kasih terhadap anak, dan konflik yang berlaku di antara ibu dan bapa. Keempat merupakan faktor individu yang berkisar tentang kurang keyakinan diri sendiri, masalah emosi, dan buntu menyelesaikan masalah yang dihadapi.

Fenomena bunuh diri di Malaysia bertambah parah dengan penularan wabak COVID-19 yang kian mengganas ini. Kehadiran varian mutasi virus COVID-19 yang semakin pantas merebak mengundang rasa cemas dan ketakutan dalam kebanyakan individu. Penularan wabak COVID-19 telah memberikan impak negatif dalam pelbagai aspek kehidupan termasuklah dalam isu kesihatan mental manusia (Rashid, Nurhafizah \& Norhamizah, 2020). Perubahan mendadak yang berlaku dalam hidup secara asasnya memberi tekanan terhadap individu. Perintah Kawalan Pergerakan (PKP) yang terlalu panjang telah memberikan impak kepada semua lapisan masyarakat tidak mengira umur, bangsa, agama dan status pekerjaan. Justeru, semasa individu berhadapan dengan krisis dan perubahan yang mendadak dalam hidup, reaksi normal yang akan ditunjukkan adalah seperti perasaan risau, takut, bimbang, sedih, tertekan, keliru, geram, malah boleh juga mendatangkan emosi marah (Lai et al., 2020; Qiu et 
al., 2020). Sekiranya kesemua perasaan ini tidak dikawal dengan baik, ia akan mengundang kepada masalah kesihatan mental yang seterusnya membawa kepada perbuatan bunuh diri.

Kajian Sharif, Rashid, Mohd Nasir dan Shukri Shuib (2013) telah dibuat untuk mengenal pasti idea bunuh diri dan hubungannya dengan kemurungan dalam kalangan pelajar kolej. Kajian ini menggunakan reka bentuk tinjauan dengan kaedah persampelan rawak mudah yang melibatkan sebanyak 65 orang responden yang dipilih secara rawak di kolej-kolej kediaman pelajar di Universiti Teknologi Malaysia. Dapatan Kajian menunjukkan idea bunuh diri pelajar berada pada tahap normal $(m=10.7)$. Selain itu, dapatan juga mendapati bahawa idea bunuh diri pelajar lelaki adalah berbeza dengan wanita di mana lelaki mencatatkan jumlah yang lebih tinggi $(\mathrm{m}=13)$ berbanding wanita $(\mathrm{m}=7.3)$ manakala bagi tahap kemurungan tiada perbezaan dicatatkan. Bangsa Melayu, Cina, India dan lain-lain bangsa pula tidak mencatatkan sebarang perbezaan dalam idea bunuh diri dan kemurungan. Hasil analisis juga mendapati idea bunuh diri dan kemurungan adalah saling berhubungan $(r=0.68)$. Implikasi kajian ini dilihat dari sudut pembangunan modal insan di mana keutamaan penting kepada penekanan aspek kesejahteraan psikologi dan kesihatan mental pelajar perlu dipertingkatkan dalam usaha membangunkan sahsiah dan pencapaian mereka di universiti.

Dalam satu kajian yang dijalankan oleh Liu, Stevens, Wong, Yasui dan Chen (2019) terhadap pelajar sarjana muda di 108 institusi pengajian tinggi di Amerika Syarikat mendapati bahawa tekanan sangat berkaitan dengan kemungkinan dalam percubaan bunuh diri dan diagnosis yang berkaitan dengan masalah kesihatan mental. Bahkan dalam kajian tersebut, majoriti pelajar turut menyatakan bahawa mereka akan mengalami tekanan sekurang-kurangnya satu hingga dua kali. Selain itu, kajian ini mendapati bahawa pelajar biseksual lebih cenderung melaporkan diagnosis masalah kesihatan mental dan bunuh diri berbanding dengan pelajar heteroseksual dan gay atau lesbian. Sebaliknya, dalam kajian lain di Malaysia ada menyatakan bahawa golongan gay dan lesbian menjadi ancaman pada cubaan membunuh diri. Hal ini bertepatan dengan kajian yang dilakukan oleh Siti Hajar, Salleh Amat dan Nasrudin (2019) yang menjalankan kaedah temu bual terhadap kaunselor yang mengendalikan kes kaunseling dengan klien gay dan lesbian yang berpotensi melakukan cubaan membunuh diri. Beberapa faktor yang menyebabkan golongan gay dan lesbian ingin melakukan cubaan bunuh diri adalah berpunca dari faktor persekitaran, konflik dalaman diri yang menjadi pendorong utama dan kemurungan yang melanda diri mereka. Hal ini berlaku apabila golongan ini mendapat tentangan hebat dari keluarga yang tidak dapat menerima pengakuan mengenai status gay dan lesbian serta dipinggirkan oleh rakan yang menyebabkan golongan ini beranggapan orang di sekelilingnya tidak mengendahkannya dan menyayanginya lagi.

Selain itu, Johari et al. (2017) pula mendapati terdapat beberapa faktor yang menyumbang kepada cubaan membunuh diri dalam kalangan rakyat Malaysia iaitu masalah teman atau keluarga, kesihatan mental, krisis kewangan, kebimbangan untuk menghadapi hukuman, penyakit fizikal yang kronik dan kurangnya sokongan. Dapatan yang sama dilihat dalam kajian yang dijalankan oleh Stuart (2013) yang mengkaji faktor-faktor bunuh diri dalam kalangan remaja mendapati bahawa faktor seperti tahap kesihatan mental, keluarga, orientasi seksual dan faktor persekitaran mempengaruhi remaja dalam cubaan membunuh diri. Malah Heng, Ling dan Victor (2019) mendapati bahawa laporan media berkaitan bunuh diri turut menjadi faktor penyumbang kepada pertambahan kadar cubaan membunuh diri.

Dalam satu kajian lain yang dijalankan oleh Kusumayanti, Swesdarma dan Nurhenti (2020) terhadap 363 orang remaja yang masih bersekolah menyatakan bahawa sebahagian besar remaja tersebut mengalami masalah kemurungan yang membawa kepada percubaan bunuh diri. Zaman remaja merupakan tahap peralihan dari zaman kanak-kanak menuju dewasa yang kritikal di mana dalam tempoh ini remaja terpaksa beradaptasi terhadap perkembangan emosi dan tingkah laku. Tambahan dari itu, Swahn et al. (2012) juga turut menjalankan kajian mengenai tingkah laku cubaan membunuh diri dalam kalangan remaja sekolah di Amerika Syarikat. Hasil kajian mendapati bahawa tahap prevalens tingkah laku cubaan membunuh diri adalah paling tinggi dalam kalangan remaja perempuan dan juga remaja yang terlibat atau terdedah kepada tingkah laku berisiko tinggi. 
Kajian yang dilakukan oleh Reynolds (1991) bertajuk Psychometric Characteristics of the ASIQ in College Students mendapati nilai kebolehpercayaan yang tinggi bagi ketekalan dalaman yang menggunakan metod alpha Cronbach's (1951) terhadap 474 pelajar kolej $(\alpha=.97)$. Manakala bagi metod ujian kembali (test-retest) yang dijalankan juga menunjukkan kestabilan skor ASIQ yang diperoleh daripada sampel kajian iaitu .86. Hal ini kerana, nilai yang diperoleh hampir sama untuk kedua-dua ujian (time 1 \& time 2) yang dijalankan dalam masa dua minggu. Ini dibuktikan lagi dengan ujian t-sampel berhubungan yang dilakukan terhadap skor ujian pertama dan kedua yang mendapati tidak terdapat perbezaan yan signifikan di antara kedua-dua skor tersebut $(\mathrm{t}(61)=.21)$ serta perbezaan min antara kedua-dua penilaian yang dibuat juga rendah (0.12). Di dalam kajian ini juga, correlations with criterion measures yang dilakukan oleh Reynolds adalah berdasarkan beberapa gagasan tekanan psikologikal seperti kebimbangan, kekecewaan, kemurungan, konsep kendiri dan individu yang mempunyai sejarah percubaan untuk bunuh diri. Gagasan yang diukur ini merekodkan hubungan yang signifikan dengan instrumen ASIQ ( $\mathrm{p}<.001)$. Namun terdapat hubungan yang agak rendah di antara ASIQ dan individu yang mempunyai sejarah percubaan untuk bunuh diri $(r=.33)$. Hal ini disebabkan oleh beberapa faktor yang digariskan oleh Reynolds dalam kajiannya, iaitu penggunaan format dikotomi dan juga kekurangan sampel bagi individu yang mempunyai sejarah percubaan bunuh diri (hanya melibatkan 6 peratus subjek).

\section{Metod Kajian}

\section{Reka Bentuk Kajian}

Kajian ini merupakan kajian kuantitatif berbentuk deskriptif dengan menggunakan pendekatan kaedah tinjauan menerusi satu edaran satu set soal selidik kepada sampel di kalangan pelajar yang dipilih dari populasi yang hendak dikaji. Populasi kajian terdiri daripada pelajar di sebuah Institusi Pengajian Tinggi Awam (IPTA) di Malaysia dan pemilihan sampel dibuat dengan menggunakan kaedah persampelan rawak mudah (random sampling). Sampel kajian terdiri daripada 120 pelajar yang dipilih secara rawak. Kaedah ini merupakan satu prosedur persampelan di mana setiap elemen dalam populasi itu mempunyai peluang yang sama untuk dipilih sebagai sampel (Sabitha Marican, 2006). Instrumen yang digunakan dalam kajian ini ialah Adult Suicidal Ideation Questinonaire (ASIQ) atau dalam bahasa Melayu soal selidik berkenaan idea bunuh diri atau pemikiran ke arah bunuh diri di kalangan individu yang mengandungi 25 item.

\section{Analisis Kebolehpercayaan}

Kajian rintis dilakukan sebelum kajian tinjauan bagi melihat tahap kebolehpercayaan alat ukur ASIQ serta mengenal pasti kesesuaian instrumen ini dalam kalangan populasi di Malaysia. Analisis kebolehpercayaan yang digunakan dalam pengujian kepada instrumen ASIQ ini adalah dengan metod ketekalan dalaman iaitu formula Alpha Cronbach's (1951) dan juga metod bahagi dua. Dalam kajian ini, pengkaji menggunakan garis panduan yang dikemukakan oleh Hair, Bush, dan Ortinau (2003) berhubung nilai kadar bagi pekali Cronbach's alpha (Alpha Coefficient Range) seperti dalam jadual di bawah;

Jadual 1: Kadar bagi pekali Cronbach's alpha

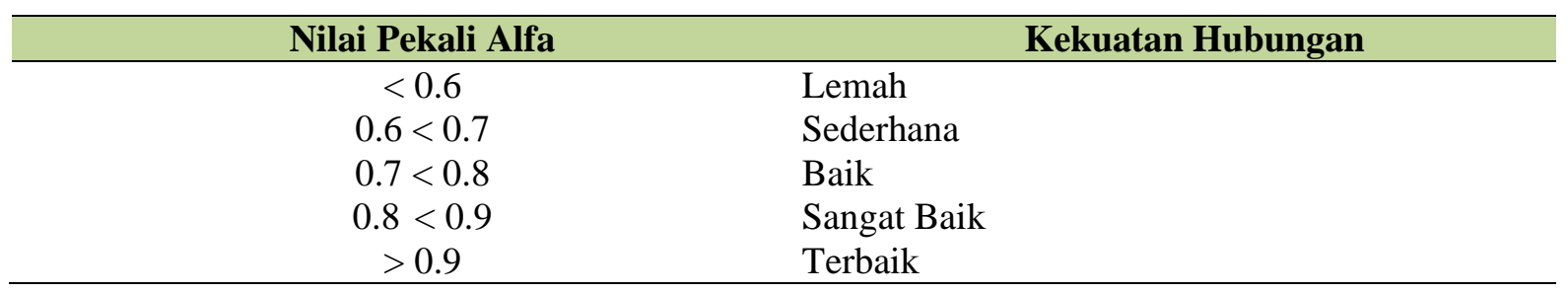


DOI: https://doi.org/10.47405/mjssh.v6i7.909

Analisis kebolehpercayaan dalaman ini dilakukan bagi memastikan item-item yang terdapat dalam alat ukur mencerminkan gagasan yang hendak diukur oleh pengkaji iaitu pemikiran dan idea untuk bunuh diri.

Jadual 2: Nilai kebolehpercayaan soal selidik kajian

\begin{tabular}{lll}
\hline Alat kajian & Nilai alpha Cronbach & Jumlah Item \\
\hline Instrumen ASIQ & 0.959 & 25 \\
\hline
\end{tabular}

Hasil analisis menunjukkan nilai alpha $(\alpha)$ yang diperoleh adalah .95. Ini menunjukkan tahap kebolehpercayaan yang tinggi bagi item-item yang mengukur pemikiran bunuh diri di dalam instrumen ASIQ. Hal ini kerana, semakin nilai menghampiri 1, bermakna item-item yang diukur mempunyai kebolehpercayaan yang tinggi.

Jadual 3: Pekali Korelasi di antara Kump A dan Kump B

\begin{tabular}{cc}
\hline Pemboleh ubah & Kump A (genap) \\
Kump B (ganjil) & $.878^{* *}$ \\
\hline
\end{tabular}

$* \mathrm{p}<.05$

Analisis kebolehpercayaan metod bahagi dua menunjukkan nilai $r=.87$. Hasil korelasi kedua-dua bahagian ini menunjukkan terdapat hubungan yang signifikan dan kuat di antara item ganjil dan genap dalam instrumen ASIQ. Pengkaji telah menggunakan formula Spearman Brown untuk memperbaiki nilai tersebut. Hasilnya menunjukkan nilai korelasi telah meningkat kepada .93.

Formula Spearman Brown adalah seperti berikut:
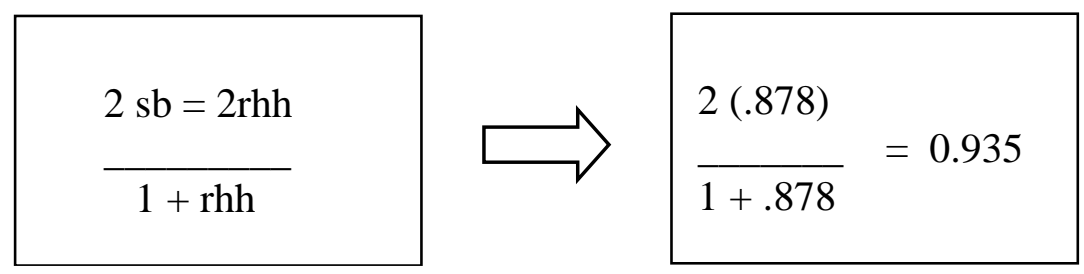

\section{Latar belakang Instrumen ASIQ}

Dalam kajian ini, latar belakang ASIQ akan dilihat dengan lebih spesifik memandangkan skala idea bunuh diri perlu ditelusuri dengan lebih mendalam untuk difahami berhubung setiap aspek instrumen ini yang merangkumi item-item, normatif, pentadbiran, skor dan interpretasinya. Pada dasarnya, sebelum ASIQ wujud, asas kepada item dan juga format yang digunakan adalah melalui Suicidal Ideation Questinonaire (SIQ). Pembangunan SIQ yang asal dilakukan pada awal 1980-an dan telah didokumentasikan di dalam SIQ Professional Manual (Reynold's 1988a). SIQ yang digunakan untuk remaja mempunyai 30 item pada awalnya dan terdapat juga instrumen SIQ-JR dalam versi 15 item yang mengukur peringkat kanak-kanak atau awal remaja. Umumnya, ASIQ adalah rentetan daripada SIQ. Kandungan asal item-item SIQ direka cipta untuk turut sama mengambil kira tahap-tahap atau hierarki pemikiran mengenai bunuh diri, dan berperingkat dari tahap lemah hinggalah ke tahap yang kritikal.

Menerusi pemerihalan yang telah dibuat dalam rajah 1 iaitu kontinum pemikiran dan tingkah laku bunuh diri, maka kecenderungan melakukan tindakan bunuh diri dilihat turut merangkumi jangkauan asas yang berkembang dari hanya pada asalannya melibatkan pemikiran dan tanggapan yang lemah sehingga berkembang kepada niat, percubaan dan tindakan yang boleh membawa maut. Secara operasionalnya, tanggapan bunuh diri yang dinyatakan merujuk kepada kehendak di mana seseorang 
menyatakan bahawa adalah baik baginya untuk tidak dilahirkan ataupun menyatakan untuk tidak lagi bernyawa. Selain itu, ia juga merangkumi tentang pemerihalan diri yang spesifik mengenai tanggapan terhadap bunuh diri dan terdapat item-item lainnya yang turut mengenal pasti secara serius tentang corak pemikiran dan tanggapan individu terhadap bunuh diri termasuk rancangan bunuh diri.

\section{Pentadbiran ASIQ}

ASIQ adalah instrumen yang mengukur pemikiran dan tanggapan individu terhadap bunuh diri. Kesemua 25 item yang terdapat dalam instrumen ini adalah mengukur cetusan pemikiran ke arah bunuh diri. Selain itu, apabila mentadbir skor dan membuat interpretasi ASIQ, pentadbir juga perlu memahami bahawa terdapat sebahagian individu yang sering memikirkan sesuatu seperti bunuh diri namun hanya berlegar dalam fikiran sahaja tanpa mengambil tindakan tersebut. Walau bagaimanapun, individu yang dikenalpasti memikirkan perihal bunuh diri secara aktif ini dapat disimpulkan sebagai manifestasi yang serius ke arah pemikiran yang salah atau maladaptive.

Instrumen ASIQ boleh ditadbir secara individu atau kumpulan kecil. Masa yang diperuntukkan untuk menjawab soal selidik lebih kurang lima minit. Suasana yang selesa tanpa sebarang tekanan yang boleh mengubah mood atau menyebabkan bias semasa menjawab (provide positive or negative selfevaluation). Tidak boleh memperkenalkan instrumen ASIQ sebagai soalselidik bunuh diri kepada responden namun boleh dinyatakan bahawa ASIQ merupakan satu instrumen yang mengukur pemikiran responden terhadap kehidupan. Hal ini bertujuan supaya lebih praktikal, objektif dan tepat menggambarkan item yang terkandung dalam ASIQ. Dalam sesetengah keadaan pula, adalah berguna sekiranya menyatakan secara tidak langsung bahawa ASIQ merupakan soal selidik yang standard dan telah diberikan kepada ribuan individu untuk menjawabnya.

Pentadbir (users) perlu melihat di dalam borang penskoran yang dilampirkan bersama soal selidik ASIQ untuk mengetahui nilai bagi setiap skala jawapan klien. Namun, penskoran juga boleh dilakukan melalui kaedah yang akan diterangkan di bawah. Setiap jawapan yang dibulatkan oleh klien hendaklah di kira mengikut nilai yang tertera bagi setiap pilihan jawapan seperti berikut;

Jadual 4: Penskoran ASIQ

\begin{tabular}{clc}
\hline & \multicolumn{1}{c}{ SKALA } & SKOR \\
\hline A & Hampir setiap hari & 6 \\
B & Beberapa kali dalam seminggu & 5 \\
C & Lebih kurang sekali seminggu & 4 \\
D & Beberapa kali dalam sebulan & 3 \\
E & Sekali dalam sebulan & 2 \\
F & Saya pernah memikirnya sebelum ini, tetapi bukan dalam bulan lepas & 1 \\
G & Saya sama sekali tidak memikirkan akan hal ini & 0 \\
\hline
\end{tabular}

Contohnya, apabila klien memilih jawapan (A) untuk item satu, maka nilai yang akan dihitung ialah 6 dan akan terus ditambah sehingga item yang terakhir (terdapat 25 item). Selepas dihitung segala nilai bagi setiap jawapan klien, isikan jumlah tersebut di dalam ruang disediakan yang bertulis ASIQ total.

Seterusnya, terdapat Critical items (CI) di dalam instrumen ASIQ yang mengukur darjah tertinggi dalam pemikiran untuk membunuh diri individu. Bagi enam CI yang dinyatakan adalah bagi item 2, 3, $4,5,15,25$, hendaklah diperiksa dengan teliti nilai yang dijawab oleh klien. Sekiranya klien menjawab A atau B iaitu nilainya 6 dan 5, maka hendaklah di tanda sebagai $X$ dalam ruang yang disediakan di bawah helaian yang ditulis 'kritikal item (CI) yang didapati'. Sebanyak enam ruang disediakan untuk enam CI yang terdapat dalam ASIQ. Secara mudahnya, sekiranya skor CI jawapan klien 5 dan ke atas nilainya, hendaklah ditulis sebagai $\mathrm{X}$ di ruang yang dinyatakan. 


\section{Interpretasi Skor ASIQ}

Interpretasi ASIQ perlu dilakukan dengan berhati-hati bagi mengelakkan sebarang kesilapan dan perlu dianalisis beberapa bahagian utama seperti skor mentah atau keseluruhan, kritikal item dan bentukbentuk jawapan klien yang direkodkan. Kaunselor yang ingin membuat interpretasi seharusnya melihat atau memeriksa kesahan jawapan klien yang mengisi soal selidik ASIQ bagi mengelakkan sebarang kesimpulan dan interpretasi yang silap. Hal ini juga bagi mengesan sekiranya terdapat jawapan yang tidak sah melalui jawapan klien yang dibuat secara berpura-pura (tidak betul). Justeru permasalahan sebenar atau tekanan yang dialami tidak dapat dilihat dan dikesan. Tujuan utama ASIQ ini juga adalah untuk membuat penilaian terhadap pemikiran terkini klien berhubung dengan bunuh diri dan bukanlah untuk mendiagnosis atau membuat ramalan tepat bahawa klien akan membunuh diri.

Skor keseluruhan bagi ASIQ ini adalah di antara 0 hingga 150. Data mentah normatif yang diperoleh dalam komuniti dewasa bagi nilai min adalah antara 7 hingga 8 , manakala bagi pelajar kolej adalah lebih kurang 11. Ini menunjukkan potensi bahawa majoriti komuniti dewasa tidak memikirkan tentang idea membunuh diri pada tahap yang tinggi. Bagi individu yang mendapat skor tinggi ASIQ, maka andaian yang dibuat adalah individu tersebut mempunyai pemikiran yang tinggi ke arah bunuh diri dan kerap memikirkannya serta dicadangkan untuk mendapatkan intervensi. Misalnya perkhidmatan kaunseling atau psikiatri. Selain itu, terdapat juga individu yang menjawab instrumen ASIQ dengan rekod yang serius dalam membunuh diri (mendapat nilai yang tinggi) bagi item 1 hingga 15, namun akhirnya mendapat skor keseluruhan yang rendah. Maka, individu tersebut telah menunjukkan tahap yang tinggi dalam idea dan pemikiran untuk membunuh diri. Jawapan yang diberikan dalam item 1 hingga 15 yang telah dijawabnya perlu diambil kira, tanpa membandingkannya (pengecualian) pada nilai keseluruhan dengan data normatif (rujukan) yang telah disediakan dalam manual.

Selain itu, terdapat nilai batasan skor yang bertujuan untuk mengenal pasti pemikiran bunuh diri individu iaitu klien yang mendapat nilai keseluruhan 31 atau lebih hendaklah dinilai lagi kerana mempunyai potensi ke arah psikopatologi dan tingkah laku bunuh diri. Nilai ini bukanlah bermakna individu itu perlu mendapat rawatan segera atau berisiko tinggi untuk bunuh diri dengan segera, namun ianya dapat dilihat sebagai idea atau tingkah laku yang signifikan ke arah menamatkan riwayat hidup. Hal ini penting untuk membuat penilaian yang seterusnya dan membuat keputusan yang lebih baik berbanding daripada tanpa ada sebarang tanda untuk mengetahui persoalan dan pemikiran yang dialami individu. Tanpa mengetahui tanda atau pemikiran ke arah bunuh diri ini, kemungkinan akhirnya boleh membawa kesan negatif seperti bunuh diri. Nilai yang dinyatakan di atas hanyalah sebagai satu indikator sahaja dalam mengenal pasti tahap pemikiran bunuh diri di kalangan responden.

\section{Intrepretasi melalui perbandingan dengan data normatif}

Selain daripada menganalisis nilai yang diperoleh menerusi ASIQ dan juga batasan nilai-nilai yang menggambarkan skala rendah dan tinggi dalam pemikiran bunuh diri, penskoran boleh juga mengambil kira perbandingan data yang diperoleh dengan data normatif ASIQ bagi semua sampel yang dilakukan seperti pelajar kolej, individu dewasa, pesakit mental dan sebagainya. Umumnya, semakin tinggi skor keseluruhan ASIQ yang diperoleh, maka semakin tinggi juga kecenderungan individu memikirkan untuk membunuh diri. Perbandingan yang dibuat ini sebagai langkah kedua yang dibuat dalam penskoran selepas menilai jumlah keseluruhan ASIQ yang diperoleh untuk setiap responden yang menjawab instrumen tersebut. Perbandingan nilai boleh dibuat dengan melihat skor T dan skor persentil dalam data normatif.

\section{Interpretasi melalui Critical Items}

Item-item kritikal di dalam ASIQ direka untuk melihat sejauh mana kecenderungan individu untuk membuat tindakan yang memusnahkan diri dan juga melihat perbezaan individu yang mempunyai sejarah untuk bunuh diri dengan individu yang tidak mempunyai sejarah tersebut. Sebagai panduan umum, sekiranya responden memperoleh item kritikal sebanyak dua atau lebih, maka individu tersebut mempunyai kecenderungan untuk memikirkan tentang bunuh diri dan data mentah bagi keseluruhan nilai ASIQ (ASIQ total) boleh diabaikan. 


\section{Interpretasi melalui item individu}

Penskoran melalui item individu ini ialah kaedah penskoran yang dilakukan untuk melihat maklum balas individu dalam menyempurnakan instrumen ASIQ. Setiap jawapan yang diperoleh bagi semua item hendaklah diperiksa semula bagi mengesan sebarang kecenderungan individu untuk membunuh diri. Misalnya, melihat kepada nilai item kritikal dan membandingkan dengan item-item lain yang dijawab oleh individu. Tindakan untuk menilai jawapan bagi setiap item individu ini akan memberikan pencerahan atau insight kepada kaunselor atau psikiatri tentang idea dan pemikiran bunuh diri dalam diri individu.

\section{Hasil Kajian dan Perbincangan Kajian}

\section{Analisis Deskriptif}

Jadual 5 di bawah menggambarkan taburan subjek kajian mengikut ciri-ciri yang terdapat di bahagian maklumat responden bagi instrumen ASIQ. Jumlah responden terdiri daripada 120 orang pelajar Universiti. Sampel dipilih secara rawak di kolej-kolej kediaman. Hasil data yang diperoleh mengikut jantina menunjukkan responden lelaki yang menjawab instrumen ASIQ adalah seramai 56 orang $(46.7 \%)$ dan perempuan pula 64 orang $(53.3 \%)$.

Jadual 5 : Latar belakang responden

\begin{tabular}{llcc}
\hline \multirow{3}{*}{ Jantina } & Demografi & Kekerapan & Peratus (\%) \\
& Lelaki & 56 & 46.7 \\
& Perempuan & 64 & 53.3 \\
Bangsa & Total & 120 & 100 \\
& Melayu & 85 & 71.0 \\
& Cina & 19 & 16.0 \\
& India & 16 & 13.0 \\
Tahap & Lain-lain & - & - \\
pendidikan & Total & 120 & 100 \\
& STPM & 5 & 4.2 \\
& Ijazah & 112 & 93.3 \\
Umur & Sarjana & 3 & 2.5 \\
& Total & 120 & 100 \\
& 20 & 18 & 15.0 \\
& 21 & 66 & 55.0 \\
& 22 & 23 & 19.2 \\
& 23 & 8 & 6.6 \\
Status & 24 & 5 & 4.2 \\
& Total & 120 & 100 \\
& Pelajar & 120 & 100 \\
& Total & 120 & 100 \\
\hline
\end{tabular}

Meneliti tentang ciri bangsa pula, didapati sebahagian besar responden terdiri dari bangsa Melayu iaitu seramai 85 orang atau $71 \%$, diikuti oleh Cina sebanyak 19 orang atau $16 \%$. Responden yang berbangsa India pula sebanyak 16 orang atau 13\%. Melihat kepada tahap pendidikan responden pula, sejumlah besar terdiri daripada peringkat ijazah iaitu 112 orang $(93.3 \%)$, dan tahap STPM pula 5 orang $(4.2 \%)$, manakala terdapat 3 orang $(2.5 \%)$ responden kajian berada di peringkat pengajian sarjana.

Selain itu, umur juga merupakan faktor yang ingin dilihat bagi memastikan jangkaan umur responden dengan skor ASIQ yang diperoleh memandangkan instrumen ASIQ memberi penekanan utama kepada 
golongon muda. Kekerapan yang tertinggi adalah responden yang berumur 21 tahun iaitu sebanyak 66 orang atau 55\%, diikuti umur 22 tahun sebanyak 23 orang (19.2\%), dan responden berumur 20 tahun serta 23 tahun mencatat nilai 18 orang $(15 \%)$ dan 8 orang $(6.6 \%)$. Kemudiannya responden berumur 24 tahun sebanyak 5 orang (4.2\%). Seterusnya, bagi status responden pula, kesemua subjek merupakan pelajar iaitu seramai 120 orang $(100 \%)$.

\section{Kekerapan Tahap Pemikiran Bunuh Diri dalam kalangan Pelajar}

Rajah 2 di bawah menunjukkan hasil tambah bagi skor responden untuk kesemua item dalam instrumen ASIQ. Pada skor yang melebihi nilai batasan (cut-off score) iaitu 31 dan lebih, menunjukkan tahap pemikiran responden ke arah bunuh diri dan memerlukan intervensi dari kaunselor mahupun psikiatri.

Rajah 2 : Jumlah keseluruhan skor responden

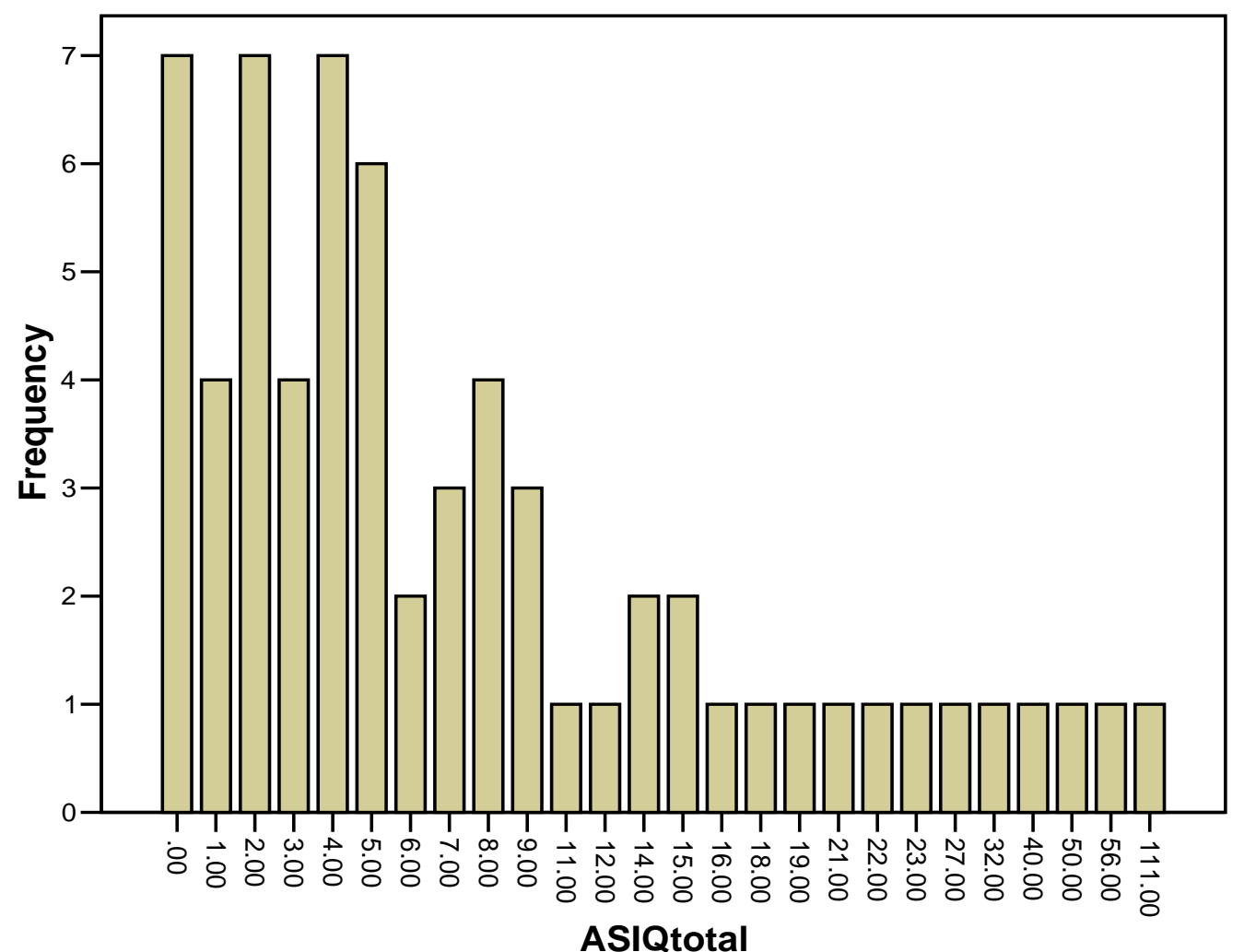

Nilai min bagi jumlah skor responden ialah 11.2, manakala sisihan piawainya 17.8. Pada jumlah skor 32 , terdapat seorang responden, bagi jumlah skor 40, 50 dan 56 juga seorang responden. Skor tertinggi iaitu 111 juga melibatkan seorang responden. Ini menunjukkan terdapat lima orang responden mencatatkan jumlah skor melebihi daripada 31 dan mereka ini memerlukan penilaian dan penerokaan dengan lebih lanjut melalui intervensi kaunseling atau klinikal. Misalnya mendapatkan perkhidmatan kaunseling atau psikiatri kerana menerusi tinjauan terhadap pemikiran bunuh diri ini membolehkan ahli psikologi, kaunselor ataupun ahli psikiatri dapat mengenal pasti bibit-bibit awal seseorang klien sama ada ianya mencapai tahap membahayakan diri, seterusnya mengenal pasti adakah klien terbabit berpotensi melakukan bunuh diri. Justeru skor dari tinjauan yang dibuat membolehkan pembacaan awal dilakukan terhadap klien yang mungkin berpotensi membunuh diri dan langkah pencegahan awal juga dapat dilakukan. Tambahan itu, item-item yang dibentuk menerusi lima soalan kritikal yang berhubung langsung dengan tanggapan bunuh diri adalah merupakan aspek utama yang perlu diberikan perhatian.

Bunuh diri merupakan isu serius yang perlu ditangani segera. Menurut laporan data yang dikeluarkan oleh Pertubuhan Kesihatan Sedunia (2020), mendapati bahawa percubaan bunuh diri berlaku setiap 
tiga saat, manakala kematian akibat bunuh diri berlaku setiap empat puluh saat yang mencatatkan hampir satu juta kematian membabitkan bunuh diri setiap tahun (World Health Organisation, 2020). Oleh yang demikian, dalam usaha untuk menjalankan sebarang intervensi, kemurungan wajar diberi perhatian dan dicegah sebelum ia menjadi parah dan diterjemahkan dalam tingkah laku bunuh diri. Pendekatan kaunseling yang memfokuskan kepada perbincangan dan pengurusan krisis merupakan alternatif dalam membawa perubahan dan kestabilan serta menurunkan risiko individu yang mempunyai idea mencederakan diri atau bunuh diri (Pelling, Bowers \& Armstrong, 2007).

Dapatan kajian juga menunjukkan purata skor terkumpul bagi idea bunuh diri pelajar kolej adalah sebanyak 11.2. Taburan min pada tahap normal adalah 11 (Reynolds, 1991). Ini menunjukkan potensi bahawa majoriti komuniti pelajar kolej tidak memikirkan tentang idea membunuh diri pada tahap yang tinggi. Walau bagaimanapun, interpretasi idea bunuh diri ini juga perlu dilakukan secara individu dengan melihat kepada nilai kritikal bagi setiap item individu yang melambangkan idea dan pemikiran mereka untuk bunuh diri. Bagi individu yang mendapat skor tinggi, maka andaian yang dibuat adalah individu tersebut mempunyai pemikiran yang tinggi ke arah bunuh diri dan kerap memikirkannya serta dicadangkan untuk mendapatkan intervensi.

Walau bagaimanapun, terdapat kajian yang mendapati bahawa responden tidak bersetuju dengan pemikiran memiliki niat untuk membunuh diri. Hal ini kerana, berdasarkan analisis temu bual yang dijalankan mendapati hadirnya tema bunuh diri bukanlah penyelesaian yang terbaik serta bunuh diri juga mendatangkan kemudaratan kepada orang lain (Siti Norma \& Salleh Amat, 2018). Berdasarkan kajian ini, didapati tidak kesemua responden mempunyai niat untuk bertindak membunuh diri secara serius dan masih boleh berfikiran waras untuk mengendalikan keadaan dan sesuatu masalah yang dihadapi. Tambahan dari itu, keluarga perlulah memainkan peranan yang penting dalam memberikan dorongan dan sokongan kepada pelajar yang mempunyai masalah berkaitan kesihatan mental. Menurut Abdul Razak (2021), ahli keluarga tidak boleh bertindak menambah lagi kedukaan individu dengan tohmahan dan kejian yang akan memburukkan lagi emosi individu terbabit. Ahli keluarga yang dapat menyediakan ruang bantuan emosi yang positif dapat menghalang daripada kemerosotan tahap kesihatan mental dan seterusnya menghindar daripada perbuatan bunuh diri. Selain itu, kajian yang dijalankan oleh Rashid, Amin, Zuraina dan Noor Dahiah (2020) menyatakan bahawa pendekatan terapi psikospiritual dengan kaedah solat, zikir, doa, amalan filantropi dan rasa redha dilihat sebagai salah satu platform alternatif yang boleh digunakan dalam menangani masalah kemurungan.

Madelyn et al. (2018) dalam kajiannya mendapati antara faktor berlakunya gangguan kesihatan mental dalam kalangan remaja dan pelajar adalah seperti kemurungan yang selalunya berlaku kepada pelajar yang menjadi mangsa penderaan, mempunyai penyakit mental yang serius, berlaku peristiwa-peristiwa besar dalam kehidupan seperti kematian, pendedahan mereka kepada orang lain yang telah membunuh diri, penyalahgunaan bahan, tekanan pembelajaran, serta masalah dalam keluarga. Remaja yang tidak dapat menguruskan tekanan-tekanan yang dihadapi dengan baik telah mengundang kepada tingkah laku membunuh diri dalam kalangan mereka. Manakala, Siti Zarinah (2019) dalam penulisannya telah mendedahkan antara faktor berlakunya masalah kesihatan mental dalam kalangan masyarakat adalah disebabkan masalah kewangan, tekanan dan beban dalam pekerjaan, tiada pekerjaan, masalah kekeluargaan seperti penceraian, kurang kemahiran keibubapaan dalam mengurus rumah tangga, keganasan, penyalahgunaan bahan, faktor persekitaran dan seumpamanya. Selain itu, kajian-kajian lepas juga mendedahkan antara faktor lain berlakunya tingkah laku bunuh diri adalah seperti kecelaruan psikiatrik, penggunaan bahan, kesihatan mental, faktor psikososial, sejarah dalam keluarga dan juga faktor biologikal (Karaman \& Durukan, 2013). Manakala Osvaldo (2012) pula mendapati faktor kewangan, tekanan, kebimbangan dan penyakit merupakan faktor paling dominan yang membawa kepada tingkah laku bunuh diri. Oleh kerana isu kesihatan mental merupakan tunjang utama berlakunya tingkah laku bunuh diri, maka dapat disimpulkan peristiwa-peristiwa tersebut juga adalah merupakan faktor kepada berlakunya tingkah laku bunuh diri. 


\section{Kesimpulan}

Bunuh diri adalah isu yang berkait rapat dengan kesihatan mental individu. Hasil kajian yang dilakukan dalam kalangan pelajar kolej mendapati bahawa idea bunuh diri tidak berada di tahap kritikal. Walau bagaimanapun, masih ada kecenderungan berfikir ke arah tersebut berdasarkan skor jawapan responden. Masyarakat harus memainkan peranan utama dengan mengambil berat terhadap tanda-tanda kemurungan yang ditunjukkan oleh remaja khususnya agar dapat dikesan dengan lebih awal dan boleh diberi rawatan dengan segera. Jika tanda-tanda ini dapat dikenal pasti, maka remaja itu sendiri, keluarga atau masyarakat boleh merujuk, mendapatkan rawatan dan khidmat nasihat daripada kaunselor atau pakar psikiatri agar penyakit tersebut boleh disembuhkan dan tidak melarat sehingga mengakibatkan idea dan pemikiran yang berkecenderungan untuk membunuh diri. Secara kesimpulannya, setiap ahli masyarakat perlulah peka terhadap kesihatan mental diri, keluarga, jiran tetangga serta komuniti setempat agar semua dapat hidup harmoni dengan menyalurkan segala tekanan yang dihadapi pada tempat dan cara yang betul. Malah, dalam menangani isu bunuh diri ini, semua pihak termasuklah ibu bapa, guru, pihak kerajaan, media dan badan bukan kerajaan haruslah menggembleng tenaga bagi mencapai hasrat tersebut.

\section{Rujukan}

Abdul Aziz, Abdul Rashid; Mohd Sukor, Nurhafizah; Ab Razak, Nor Hamizah. (2020). Wabak Covid19: Pengurusan Aspek Kesihatan Mental Semasa Norma Baharu. International Journal of Social Science Research, 2(4), 156-174. http://myjms.mohe.gov.my/index.php/ijssr/article/view/11594

Abdul Aziz, A. R., Shafie, A. A. H., Ali, Z., \& Dzainal, N. D. S. (2020). Pengamalan Nilai Agama dalam Mengatasi Kemurungan Semasa Pandemik COVID-19. Malaysian Journal of Social $\begin{array}{lll}\text { Sciences } \quad \text { Humanities (MJSSH), } & \text { 5(12),31-44. }\end{array}$ https://doi.org/https://doi.org/10.47405/mjssh.v5i12.593

Abdul Razak Abdul Manaf (2021). Sokongan dan Dorongan Positif Keluarga Penting untuk Elak Kejadian Bunuh Diri. Dicapai pada 2 Jun 2021 daripada https://webcache.googleusercontent.com/search?q=cache:4jiAeI7wt4J:https://www.bernama.com/bm/news.php\%3Fid\%3D1977690+\&cd=7\&hl=en\&ct=clnk\& $\mathrm{gl}=\mathrm{my}$

Ame Husna Kamina \&, Salleh Amat. (1995). Persepsi Kaunselor terhadap Isu berkaitan Bunuh Diri dan Idea Membunuh Diri: Satu Analisa. Sosial Science Graduate International Seminar.

Data \& Statistics Fatal Injury Report (2019). Centers for Disease Control and Prevention (CDC). Dicapai pada 1 Julai 2021 daripada https://webappa.cdc.gov/sasweb/ncipc/mortrate.html

Editor Bernama (12 Mac 2019). Gara-gara cinta ditolak, pelajar panjat bumbung nak bunuh diri, Garagara cinta ditolak, pelajar panjat bumbung nak bunuh diri. BERNAMA. Capaian pada 4 Julai 2021. https://www.malaysiakini.com/news/467650.

Editor Bernama. (16 Mei 2021). Bunuh Diri Kerana Undian Instagram, Mereka yang Mengundi Boleh Didakwa. BERNAMA, Capaian 4 Julai 2021. https://orangkata.my/berita/bunuh-diri-keranaundian-instagram-mereka-yang-mengundi-boleh-didakwa/

Elena, A. G., David. M. G., Fernando, R.A., \& Esther, G.E. (2018). Sedentary behaviors, physical activity, and changes in depression and psychological distress symptoms in older adults, Depress Anxiety, 35, 884-897.

Foster, T., Gillespie, K., \& McClelland, R. (1999). Risk Factors for Suicide Independent of DSM IIIR Axis I Disorder. British Journal of Psychiatry, 175, 175-179.

Hafidzul Hilmi. (1 Julai 2021). Purata dua kes bunuh diri setiap hari - Polis. Metro Online, Capaian pada 3 Julai 2021. https://www.hmetro.com.my/utama/2021/07/724984/purata-dua-kes-bunuhdiri-setiap-hari-polis.

Hair, J. J., Bush, R. P., \& Ortinau, D. J. (2003). Marketing research: within a changing information environment. New York (NY): McGraw-Hill/Irwin.

Heng, J. G., Ling, T. P., \& Victor, J. G. (2019). A framing analysis of news coverage on suicide by Utusan Malaysia and Kosmo! Paper presented at 6th International SEARCH Conference, Taylor's University, Kuala Lumpur, Malaysia. 
DOI: https://doi.org/10.47405/mjssh.v6i7.909

Hong Kok Pan \& Mohammad Aziz Shah. (2018). Inventori Kecenderungan Bunuh Diri. International Journal of Academic Research in Business and Social Sciences, 8(2), 475-489.

Jianbo Lai et al. (2020). Factors Associated with Mental Health Outcomes Among Health Care Workers Exposed to Coronavirus Disease 2019. JAMA Netw Open, 3(3), e203976. doi:10.1001/jamanetworkopen.2020.3976

Johari, M. A., Shukri, M. Z. M., Abd Karim, M. A. S., Hakim, M. H. I., Khazali, A. K., A., Nasarudin, A. A., Rahimi, M. A. M., 'Imi, M. A., Mohamad, M. H., Salmi, R. (2017). Perception of media in reporting suicide cases in Malaysia. Journal of Advanced Research in Social and Behavioural Sciences, 7(1), 59-67.

Juhnke, G.S., Granello, D.H., \& Granello, P.F. (2011). Suicide, self-injury and violence in the scholls. Assessment, prevention and intervention strategies. New Jersey: John Wiley and Son, Inc.

Karaman, D., \& Durukan, I. (2013). Suicide in Children and Adolescents. Current Approaches in Psychiatry, 5(1), 30-47.

Kementerian Kesihatan Malaysia. (2016). Masalah Kesihatan Mental di Malaysia.

Khairunnezam Mohd Noor. (2018). Kemurungan dan panduan islam dalam menghadapinya. Nilai: Universiti Sains Islam Malaysia.

Kumara. (10 May 2021). Tertekan tiada pekerjaan, lelaki cuba terjun dari tingkat 11. Malaysia Gazzete.

Laporan Tahunan Kementerian Kesihatan Malaysia (2013). Kementerian Kesihatan Malaysia. Kuala Lumpur.

Liu CH, Stevens C, Wong SHM, Yasui M, \& Chen JA. (2019). The prevalence and predictors of mental health diagnoses and suicide among U.S. college students: Implications for addressing disparities in service use. Depress Anxiety, 36, 8-17. https://doi.org/10.1002/da.22830

Louise, B. (2018). Suicide Risk and Mental Disorders. Int J Environ Res Public Health, 15(9).

Mahmood Nazar Mohamed. (2005). Pengantar psikologi; Satu pengenalan asas kepada jiwa dan tingkah laku manusia. Kuala Lumpur: Dewan Bahasa dan Pustaka.

Madelyn, S., \& Alison, M., \& Kleinman, M., \& Galfalvy, H. \& Chowdhury, S., \& Madnick, A. (2018). Exposure to Suicide in High Schools: Impact on Serious Suicidal Ideation/Behavior, Depression, Maladaptive Coping Strategies, and Attitudes Toward Help-Seeking. Int. J. Environ. Res. Public Health, 15(3), 455.

Maniam Thambu. (2010). Hidup atau mati: Masalah bunuh diri di malaysia dari perspektif psikiatri. Bangi: Penerbit UKM.

Matthew K. N, Guilherme, B., Evelyn J. B., Christine B. C., Ronald, C. K., \& Sing, L. (2008). Suicide and Suicidal Behavior, Epidemiologic Reviews, 30, 133-154.

Mazza, J.J., \& Reynolds, W.M. (2001). An investigation of psychopathology in nonreferred suicidal and nonsuicidal adolescents. Suicide and Life Threatening Behaviors, 31, 282-302.

Mohd Suhaimi \& Rozita. (2017). Perbezaan Gender Tekanan Psikologikal dan Kesihatan Mental dalam Kalangan Pelajar Prasiswazah. Jurnal Personalia Pelajar, 21(1), 55-66.

Mohamed Hatta Shahrom. (2007). Psikologi dan kaunseling remaja. Kuala Lumpur: PTS Publication \& Distributors Sdn. Bhd.

Mohammad Abu Bakar Shis (2010). Kajian Gejala Sosial di Kalangan Pelajar Institusi Pengajian Tinggi yang menetap di Kolej Sembilan (K9) dan Koleh Perdana (KP), Universiti Teknologi Malaysia. Laporan projek ini dikemukakan sebagai memenuhi syarat penganugerahan Ijazah Sarjana Muda Sains Serta Pendidikan (Fizik), Fakulti Pendidikan, Universiti Teknologi Malaysia.

Nurul Sofiah Ahmad Abd Malek, Noraini Abdol Raop \& Mohd Sufiean Hassan. (2020). Peranan Kesihatan Mental Sebagai Moderator Terhadap Kecenderungan Bunuh Diri. Malaysian Journal of Social Science, 5(1), 87-99.

Osvaldo, P, A., Brian, D. \& John, S., (2012). Factors associated with suicidal thoughts in a large community study of older adults, The British journal of psychiatry, 201(6), 466-72.

Pelling, N., Bowers, R., \& Armstrong, P. (2007). The practice of counselling. Sydney: Thomson.

Qiu, J., Shen, B., Zhao, M., Wang, Z., Xie, B., \& Xu, Y. (2020). A nationwide survey of psychological distress among Chinese people in the COVID-19 epidemic: implications and policy recommendations. General psychiatry, 33(2), e100213. https://doi.org/10.1136/gpsych-2020100213.

Rafidah Mat Ruzki dan Mohd Nasaruddin Parzi. (19 Mei 2020). COVID-19: Masalah emosi isu utama kesihatan mental rakyat, Berita harian Online, Capaian pada 4 Julai 2021. 
DOI: https://doi.org/10.47405/mjssh.v6i7.909

https://www.bharian.com.my/berita/nasional/2020/05/690727/covid-19-masalah-emosi-isuutama-kesihatan-mental-rakyat

Reeves, A. (2010). Counseling Suicidal Clients. London: SAGE Publication Ltd.

Reynolds, W. M. (1991). Psychometric Characteristics of the Adult Suicidal Ideation Questionnaire in College Students, Journal of Personality Assessment, 56(2), 289.

Reynolds, W.M. (1991). Adult Suicidal Ideation Questionnaire Professional Manual. Florida: PAR.

Reynolds, W. M. (2002). Professional Manual Reynolds Adolescent Depression Scale 2 (RADS-2). California. PAR.

Sabitha Marican. (2006). Penyelidikan sains sosial: pendekatan pragmatik. Batu Caves: Edusystem Sdn. Bhd.

Shadrina M, Bondarenko EA \& Slominsky PA. (2018). Genetics Factors in Major Depression Disease. Front Psychiatry, 9, 334.

Sharif Mustaffa, Mohamed \& Abdul Aziz, Abdul Rashid \& Nasir, Mohd \& Shuib, Shukri. (2013). Depression and Suicidal Ideation among University Students. Procedia - Social and Behavioral Sciences. 116. 10.1016/j.sbspro.2014.01.917.

Siti Azila (6 Feb 2020). Siasat dakwaan pelajar bunuh diri akibat tekanan di sekolah, Berita Harian Online, Capaian pada 4 Julai 2021.

https://www.bharian.com.my/berita/kes/2020/02/653217/siasat-dakwaan-pelajar-bunuh-diriakibat-tekanan-di-sekolah

Siti Hajar Jamal, Salleh Amat, Nasrudin Subhi. (2019). Kecenderungan cubaan membunuh diri dalam kalangan gay dan lesbian di Malaysia. Jurnal Pendidikan Malaysia, 44(1), 151-162.

Siti Norma Aisyah Malkan@Molkan \& Salleh Amat. (2018). Pengetahuan dan Kefahaman Pelajar Kolej Terhadap Niat Bunuh Diri. Jurnal Hadhari, 10(1), 29-48. ejournals.ukm.my/jhadhari

Siti Zarinah Sahib. (20 Sep 2019). Derita Dalam Senyap. Harian Metro, Capaian pada 3 Julai 2021. https://www.hmetro.com.my/hati/2018/04/327729/derita-dalam-senyap

Stuart, W. G. (2013). Prinsip dan Praktik Keperawatan Kesehatan Jiwa. Vol 1\&2. Singapore: Elsevier

Swahn, M.H., Ali, B., Bossarte, R. M. Dulmen, M. V., Crosby, A., Jones, A.C., \& Schinka, K. C. (2012). Selfharm and suicide attempts among high-risk, urban youth in the U.S: Shared and unique risk and protective factors. International Journal of Environmental Research and Public Health, 9, 178-191.

The National Suicide Registry Malaysia Annual Report (2010). Ministry of Health, Malaysia.

World Health Organization. (2020). World health statistics 2020. World Health Organization. https://apps.who.int/iris/handle/10665/44292

World Health Organization (2021). Suicide. Dicapai pada 30 Jun 2021 daripada https://www.who.int/news-room/fact-sheets/detail/suicide 